Undas Vol 12. , Nomor 2, Desember 2016 : 99--116

\title{
SASTRA BANJAR KALIMANTAN SELATAN PASCA KEMERDEKAAN
}

\author{
Banjar Literature of South Kalimantan Post Independence Age \\ Saefuddin \\ Balai Bahasa Kalimantan Selatan \\ Jalan Jenderal Ahmad Yani Km 32,2, Loktabat, Banjarbaru 70712 Kalimantan Selatan \\ Telepon (0511) 4772641, Posel: kangasef@yahoo.co.id
}

\begin{abstract}
Abstrak: Sastra Banjar Kalimantan Selatan pascakemerdekaan menggambarkan tentang peristiwa yang melatarbelakangi kehidupan penulis dan masyarakatnya. Peristiwa-peristiwa itu terjadi dalam kehidupan yang memiliki latar belakang berbeda dengan daerah lain. Sastra Banjar dan penulisnya memiliki kekhasan masing-masing dari waktu ke waktu. Perkembangan sastra pascakemerdekaan tahun 1950-1959 memiliki ciri yang khas, meskipun karya sastra yang berkembang memiliki kategori yang sama, yakni puisi, prosa, dan drama. Ciri-ciri yang khas itu, dapat dikatakan karena beberapa faktor, antara lain karena bangsa ini kondisi transisi pascakemerdekaan. Berdasarkan uraian itu, masalah dalam penelitian ini akan membahas tentang perkembangan sastra pascakemerdekaan tahun 1950-1959 dengan latar belakang kehidupan masyarakatnya sebagai pemilik sastra daerah Banjar di Kalimantan Selatan. Penelitian ini menggunakan metode deskriptif-kualitatif. Metode ini digunakan untuk memperoleh informasi tentang perkembangan sastra daerah di Kalimantan Selatan dan kemudian menjadi bahan analisis. Penelitian ini akan memberikan gambaran tentang kondisi kesusastraan di Kaliantan Selatan pasckemerdekaan.
\end{abstract}

Kata kunci: Sastra Banjar, pascakemerdekaan.

Abstract: Banjar literature of South Kalimantan post independence describes obaut event that becames the backgraound of the writei's life and its society. Each events has different backgraound with other region. Banjar literature and the writer have special characteristic from time to time. The development of literature post independence age in 1950 - 1959 has special characteristic, even thougt the literature has the same catagoris, they are poem, prose, and drama. That special characteristic can be because of reveral factors, for example when this nation is in transition condition post independence. Base on the explanation, the problem in this study will discuss abaut the development of literature post independence in 1950 - 1959 whith the background of its social life as the owner of Banjar local literature in South Kalimantan. This study is used descriptive qualitative method. This method is uses to get information abaut the development of local literature in South Kalimantan and it becomes the data. This study will give description abaut the condition of literature is South Kalimantan post independence.

Key words: Banjar literature post independence.

\section{PENDAHULUAN}

Karya sastra, seperti halnya di daerahdaerah lain di Indonesia, di Kalimantan Selatan berkembang sastra daerah, baik yang berbentuk lisan maupun tulisan, yang kemudian disebut sastra Banjar. Sastra lisan itu, tumbuh sebagai tradisi yang sudah ada sejak nenek moyang beberapa tahun silam. Di samping itu, telah berkembang pula karya sastra yang dihasilkan oleh sastrawan Kalimantan Selatan masuk dalam sejarah 
sastra Indonesia juga menambah jumlah perkembangan sastra Indonesia. Karyakarya yang dihasilkan itu berupa puisi, prosa, dan drama sebagai bentuk karya sastra yang modern, di samping sastrasastra lisan yang dimaksud di atas.

Jika kita menempatkan sastra dalam lokasi perkembangan secara nasional, sastra daerah termasuk bagian penting atas tumbuhkembangnya sastra Indonesia, dalam arti bahwa sastra daerah itu milik bangsa Indonesia. Jika dilihat dari segi usaha mewujudkan kebudayaan nasional Indone-sia, jelas bahwa sastra merupakan unsur kebudayaan nasional. Hal tersebut ditegas-kan oleh Teeuw (2013), bahwa ada kerugian untuk membagi-bagi sastra Indonesia menurut bahasanya, tanpa memperhatikan keseluruhan dan kesatuan sastra Indonesia. Teeuw menyarankan agar sastra Indonesia diteliti sebagai bidang dengan memper-hatikan beberapa hal, seperti sejarah dan perbandingan sastra, tipologi, metode, dan manfaatnya sehubungan dengan semboyan bhineka tunggal ika. Pernyataan itu menunjukkan bahwa istilah sastra Indonesia digunakan dalam arti keseluruhan sastra yang tumbuh dan berkembang di Indonesia.

Perkembangan sastra Indonesia di Kalimantan Selatan khususnya di kota Banjarmasin dan umumnya kota dan kabupaten lain di Kalimantan Selatan tidak bersamaan dengan kota-kota lain yang lebih maju; seperti di Pulau Jawa, Sumatera, dan Bali. Di kota-kota itu telah lahir sastra Indonesia sejak awal sekitar abad ke-20. Sastra Indonesia di Kalimantan Selatan dalam catatan kelahirannya ialah sekitar menjelang abad pertengahan. Namun, posisinya belum dapat disejajarkan dengan kota-kota yang ada di Jawa, Sumatera, dan Bali tersebut. Dari hasil dokumentasi atau laporan penelitian sastra Indonesia lahir sekitar abad ke20 (Effendi dkk. 1992) dan (Jarkasi dkk. 2002), yaitu setelah kemerdekaan Indonesia tahun 1945. Setelah tahun tersebut, keber- adaan sastrawan yang menghasilkan karya dalam genre sastra modern, merupakan awal kelahiran sastra Indonesia di Kalimantan Selatan. Bermula dari tahun itu pula, peluang untuk mengembangkan kreativitas sastra makin terbuka luas. Perkembangan menunjukkan kemajuan setelah adanya berbagai sarana dan prasarana, berupa tersedianya sarana pendidikan, terbentuknya organisasi-organisasi seni budaya atau sanggar-sanggar, misalnya adanya Koordinasi Kesenian Nasional Indonesia (BKKNI) Kalimantan Selatan, Dewan Kesenian Daerah (DKD) Kalimantan Selatan, dan Taman Budaya di Banjarmasin serta sanggar-sanggar seni di daerah dan kota lainnya, juga terbukanya media massa dan semakin membaiknya kehidupan sosial budaya dan ekonomi masyarakat jika dibandingkan dengan keadaan sebelumnya.

Selain itu, terbukanya dunia pendidikan baik yang bersifat formal maupun nonformal semakin membuat keadaan masyarakat dan menambah nuansa berpikir serta dinamika sosial dalam berbagai aspek kehidupan di masyarakat Kalimantan Selatan. Banyak sastrawan-sastrawan daerah ini melanjutkan pendidikan dan ternyata sebagian dari mereka mendalami bidang seni dan budaya; ada yang memperdalam bidang sastra atau kesusastraan di daerahnya dalam hal ini Kalimantan Selatan, seperti di Banjarmasin, baik secara otodidak maupun melalui pendidikan formal dan adapula yang ke luar Kalimantan Selatan, seperti di Pulau Jawa.

Sekembalinya dari menempuh pendidikan, mereka mengembangkan ilmu dan pengalaman yang diperolehnya selama pendidikan di kota-kota yang dunia sastranya lebih maju. Ada di antara mereka yang membentuk organisasi seni budaya sebagai sanggar/wadah dalam kegiatan apresiasi seni, seperti di Kota Banjarmasin. Organisasi itu bertujuan untuk menghimpun orang-orang yang memiliki bakat seni, baik bagi mereka yang pernah mengenyam 
pendidik-an di perguruan tinggi maupun yang hanya sekolah tingkat menengah. Dengan demi-kian, terbentuknya organisasi-organisasi seni budaya tersebut sangat besar peran-annya dalam menyemarakkan kehi-dupan sastra di Kalimantan Selatan, walaupun diakui karya-karya yang mereka hasilkan belum dapat disejajarkan dengan karya-karya sastrawan dari daerah lain yang namanya telah tercatat dalam peta kesejarahan seperti wilayah Jawa dan Sumatera dalam sastra di Indonesia. Namun, bukan berarti tidak ada dari sejumlah nama-nama sastrawan Kalimantan Selatan yang masuk dalam daftar peta kesejarahan sastra Indonesia. Beberapa surat kabar lokal yang pernah memuat dan menyediakan ruang sastrabudaya, misalnya Banjarmasin Post, Dinamika Berita, dan Radar Banjarmasin, dan koran-koran lain yang terbit belakangan.

Di samping itu, kehadiran surat kabar di daerah ini sangat berperan dalam membantu perkembangan kehidupan sastra. Peranannya sebagai media komunikasi mampu menyajikan atau menampilkan hasil kreativitas dan apresiasi para sastrawan lokal. Ruang seni dan budaya di surat kabar itu selalu dihiasi oleh karya-karya sastra, baik yang berbahasa daerah (Banjar) maupun yang berbahasa Indonesia. Sema-raknya dunia kepengarangan di Kalimantan Selatan dari awal kelahirannya sampai sekarang mendorong keinginan penulis untuk mengetahui secara lebih mendalam mengenai peranan pengarang dalam kehidupan kesusastraan Indonesia di Kalimantan Selatan dalam priodisasi tertentu. Seberapa besar memberikan kontribusi tentang perkembangan kesusastraan di Kalimantan Selatan atau corak apa yang berkembang dalam sejarah perkembangan kesusastraan di Kalimantan Selatan. Oleh karena itu, tulisan ini dengan segala keterbatasannya dan boleh jadi ini akan memberikan sumbangan pemikiran untuk tulisan berikutnya yang lebih lengkap, sehingga perkembangan atau sejarah perkembangan sastra di Kalimantan Selatan dapat dijadikan bahan tambahan informasi bagi guru bahasa dan sastra Indonesia di sekolah untuk diketahui lebih lanjut oleh generasi-genrasi berikutnya.

Oleh karena itu, tulisan tentang perkembangan sastra di Kalimantan Selatan dan kondisi masyarakat kepengarangan sangatlah penting untuk diteliti dalam memberikan gambaran tentang fenomena itu, dalam arti studi itu memberikan manfaat dan berguna bagi masyarakat. Pertama, sebagai alat pembantu untuk membuat tafsiran-tafsiran karya sastra. Kedua, sebagai bahan untuk menyusun perkem-bangan sejarah sastra. Ketiga, sebagai bahan lain, misalnya mengenal pengarang, menge-nal tempat hidup yang berguna bagi sejarah sastra, dan sebagainya.

Penelitian mengenai perkembangan sastra di suatu wilayah untuk menuju Indonesia secara keseluruhan merupakan penelitian yang didasari pada asumsi bahwa karya sastra sebagai hasil cipta kreatif dari seorang pengarang (Damono, 1997). Lahirnya sebuah karya sastra tidak dapat dilepaskan dari kehadiran seorang pengarang. Karena itu, perkembangan kesusastraan di suatu wilayah tertentu akan menjadi hal yang cukup penting dalam studi sastra. Studi semacam ini akan bernilai sejauh dapat memberikan masukan dalam penciptaan karya sastra (Wellek dan Warren, 1989:82).

Pengarang ialah anggota masyarakat, dia mencipta sebuah karya sastra bukan tanpa latar belakang yang kosong (Damono, 1984:23). Pengarang sebagai manusia memiliki perilaku yang mengarah pada pemahaman arti terhadap aktivitas subjeksubjek yang terbentang di sekitarnya. Perilaku tersebut, dimaksudkan untuk menciptakan stabilitas dan kedamaian. Tendensi penciptaan stabilitas dan kedamaian ini dibangun dari keseimbangan baru 
merupakan produk kegiatan manusia untuk memberi makna agar tetap manusiawi. Dengan demikian, penciptaan sebuah karya sastra merupakan sebuah proses panjang yang telah dilalui oleh seorang pengarang sebagai usaha untuk memahami masyarakat. Proses penciptaan yang panjang itu dapat diteliti lewat latar belakang kehidupan pengarangnya (Mujiningsih, 1995:1).

Pencatatan data historis sastra Indonesia di Kalimantan Selatan selama ini masih dirasa kurang. Sastra yang berkembang di daerah merupakan salah satu mata rantai sastra nasional yang banyak sedikitnya memiliki hubungannya dengan perkem-bangan sastra Indonesia modern. Ini disadari oleh adanya hasil-hasil sastra yang berkembang di luar pulau Jawa sebetulnya juga hasil pemikiran masyarakat Indonesia. Karena itu, upaya perekaman dan rekon-struksi sastra Indonesia di daerah perlu dilakukan secara berkesinambungan.

Bahan-bahan sastra, khususnya yang menyangkut sastra modern di daerah Kalimantan Selatan belum banyak diteliti. Penelitian yang pernah dilakukan dan telah disebutkan di atas, yakni Kesusastraan Indonesia di Kalimantan Selatan oleh Effendi dkk. (1993). Penelitian ini menfokuskan penginventarisasian penyair Indonesia di Kalimantan Selatan beserta karya-karya mereka. Penelitian kedua pernah dilakukan oleh Jarkasi dkk (1996). dalam judul, Sejarah Pertumbuhan Sastra Indonesia di Kalimantan Selatan Tahun 1930-1949. Masalah yang dikaji dalam penelitian ini, ialah kondisi sosial politik yang berpengaruh dalam dunia kepenga-rangan di Kalimantan Selatan. Ini terlihat dalam tema-tema pilihan yang ditulis oleh para pengarang dalam kurun waktu itu.

Jika diamati dari dua hasil penelitian ini, sastra Indonesia di Kalimantan Selatan dapat dinyatakan telah lama berkembang paling tidak, pengarang-pengarang Indone- sia di daerah Kalimantan Selatan sudah melakukan kegiatan kepengarangan, khususnya dalam menulis sastra modern sejak sebelum perang kemerdekaan. Hal ini diperkuat lagi oleh pengamatan budayawan Kalimantan Selatan, Yustan (1975) yang menyatakan bahwa sastra Indonesia di Kalimantan Selatan dapat diklasifikasikan ke dalam beberapa periode pertumbuhan, yakni (1) periode sebelum perang, (2) periode pendudukan Jepang/ revolusi fisik, (3) Periode 1950-an, (4) Periode 1960-an, dan (5) periode menjelang dan sesudah tahun 1970-an. Klasifikasi yang dikedepan-kan oleh Yustan ini tentu dilihat berdasar-kan beberapa latar belakang sosial politik yang mendasari munculnya periodisasi sastra itu (Yustan, 1975:48).

Berbeda dengan itu, kajian yang dilakukan dalam tulisan ini ialah mengama-ti secara sistematis perkembangan sastra Indonesia di Kalimantan Selatan tahun 1950-1959. Perkembangan di tahun ini merupakan periode pascaperang kemer-dekaan, yang tentu juga memiliki latar belakang sosial yang tidak sama dengan kondisi sosial budaya dengan daerah lain di Indonesia. Tahun 1949, di Kalimantan selatan telah diproklamirkan Pevisi IV ALRI Pertahanan Kalimantan, sebagai titik awal perjuangan rakyat Kalimantan Selatan terhadap agresi ke-2 dari Belanda. Masa ini juga dikenal sebagai masa transisi untuk melakukan penataan pembangunan daerah Kalimantan Selatan bagi mereka yang dipandang terpelajar pada masa itu. Walaupun kondisi sosial budaya daerah Kalimantan Selatan telah memasuki fase baru dalam sejarah Indonesia, tetapi perlu diketahui pula, bahwa tradisi lisan masih kuat berakar di daerah ini. Karena itu. dapat diduga bahwa perkembangan sastra modern belum terlalu tampak dalam fase ini. Fase ini tetap menjadi catatan, sebab setelah tahun 1955, keadaan sosial budaya sudah mulai kembali dan sebagian besar orang-orang terpelajar 
pada masa itu sudah menampakkan keaktifannya dalam hal tulis menulis. Pada masa itu, beberapa aspek kreativitas sastra dilakukan dalam beberapa cara seperti penulisan dalam bentuk puisi, prosa, juga karya-karya drama secara perorangan dan belum terbentuk komunitas sastrawan Kalimantan Selatan. Oleh karena itu, aspekaspek tulisan yang dilakukan perlu pula dicermati berkenaan dengan aspek sistem penulisan, sistem pembinaan, sistem pembaca, sistem publikasi, dan sistem kritik. Sejauh mana sistem-sistem ini dilakukan oleh penulis-penulis Kalimantan Selatan, untuk itu perlu dilakukan penelitian.

\section{KERANGKA TEORI}

Karya sastra merupakan hasil pikiran manusia yang memiliki kerumitan tersen-diri. Kerumitan ini diketahui karena sastra selalu mempermasalahkan banyak peristiwa dalam kehidupan manusia seperti kese-dihan, kegembiraan, politik, yang melatar-belakangi kehidupan pengarangnya. Peris-tiwa-peristiwa yang terjadi dalam kehi-dupan seseorang dalam kelompok orang sering menjadi inspirasi penulisan sastra. Dengan demikian, sastra dapat diakui sebagai pantulan kehidupan, baik dalam hubungan antarorang seorang maupun antarseorang dengan masyarakat, bahkan lingkungan (Damono, 1983: 1).

Karya sastra yang lahir dan berkembang di suatu daerah sering disebut karya sastra daerah. Namun, tidak semua karya sastra itu disebut karya sastra Indonesia, sebab untuk menyebut karya sastra Indonesia mestilah ada beberapa kriteria yang mesti diikuti. Damono mengu-raikan bahwa karya sastra yang ditulis dalam bahasa Indonesia oleh penulis yang berkewarganegaraan Indonesia atau pribumi Indonesia, baik tinggal di Indonesia maupun di luar Indonesia, juga karya sastra yang ditulis oleh warga negara Indonesia atau pribumi Indonesia dalam bahasa yang ada di Indonesia, baik yang tinggal di Indonesia maupun di luar Indonesia (Damono, 1983: 131-132). Karya sastra dengan karakter seperti itu ialah karya sastra Indonesia.

Apa yang disajikan dalam dunia sastra tidak lepas dari peristiwa sehari-hari yang terjadi. Karena itu, karya sastra akan selalu berkaitan dengan unsur-unsur budaya masyarakat. Rene Wellek dan Austin Warren (1991: 154) menyebutnya, karya sastra merupakan cermin masyarakat. Karya sastra yang ditulis oleh penulis daerah dalam bahasa Indonesia tentu juga bagian dari sastra Indonesia. Sebab, secara psiko-logis sastrawan tersebut sudah menyatakan di dalam pengungkapan sastra berbahasa Indonesia. Berbeda dengan itu, karya sastra yang mereka tulis dalam bahasa Banjar misalnya, bukanlah bagian dari sastra Indonesia, sebab bahasa yang mereka pilih ialah bahasa daerah. Dengan demikian, segala aspek pikiran dan pandangannya bukanlah untuk orangorang atau pembaca yang lebih umum.

Garis pertumbuhan dunia sastra di suatu daerah tidak bisa dilepakan pula dari bangun sistem yang membentuknya. Sistem itu antara lain ialah; sistem pengarang, sistem pembaca, sistem produksi, sistem kritik, sistem pengungkapan. dan sistem publikasi. Secara proporsional kita dapat mengatakan, sebuah karya sastra tidak mungkin bisa lahir tanpa ada pengarang sastra. Kelahiran pengarang itu juga tidak bisa lepas dari identitas pengarang seperti agama, pendidikan, profesi, latar 
belakang sosial, ideologi, dan pekerjaan. Sastra muncul untuk dibaca oleh pcminatnya. Bagaimanakah karya sastra ini dapat sampai ke tangan pembaca? Tentu karena ada sistem publikasi. Melalui sarana apa saja publikasi ini dilakukan? Apakah bantuan penerbit ataukah sekadar didistribusikan secara manual menggunakan sistem kirim berikirim secara individual.

Sistem lain ialah, sistem pengayom dan sistem kritik. Keabadian sistem pengayom dalam sebuah kondisi pengembangan dunia sastra sangat penting. Setidak-tidaknya, rekadaya pertumbuhan dunia sastra dalam kadar sebagai pemberi rangsangan untuk dapat terus berkarya diperlukan semangat. Semangat yang diberikan, baik secara perorangan maupun oleh pihak pemerintah ialah bagian dari sistem pengayom tersebut. Sistem berikutnya ialah sistem kritik. Sistem ini terbangun oleh orang-orang yang merasa peduli dengan kehadiran karya sastra. Mereka menganggap bahwa dunia sastra ialah dunia yang memiliki kadar-kadar prinsip berpikir. Penomena berpikir ini merupakan sebuah keadaan untuk mengetahui, apakah karya sastra memang membawa prinsip-prinsip zamannya atan sekaligus merupakan kemajuan dalam hal obsesi perorangan. Sistem kritik memang berkaitan dengan sistem pembaca. Kema-juan dalam sistem pembaca melahirkan sistem kritik. Pembaca sastra akan memberikan indikasi, apakah suatu karya sastra memiliki pengaruh terhadap kondisi sosial masyarakat atau tidak. Kalangan apa saja yang mengakrabi karya sastra tersebut dan bagaimana konsep-konsep yang di kede-pankan oleh seorang sastrawan.
Yang berikutnya ialah sistem pengung-kapan yang sering disebut style. Bentuk pengungkapan sastra yang bagaimana yang banyak dilakukan oleh sastrawan pada kurun masa tertentu? Apakah mereka senang menulis, baik puisi, prosa, maupun drama. Kemudian, apakah juga pengung-kapan dengan sastra tersebut memberi karakter pada gaya-gaya tertentu. Hal ini berkait pula dengan gaya penceritaan, gaya penulisan puisi. berirama ataukah mengikuti bentuk-bentuk sebagaimana dilakukan oleh pengarang-pengarang Indonesia yang popu-ler pada zaman itu. Selanjutnya, sistem-sistem ini akan menjadi fokus dalam tulisan ini.

\section{ANALISIS DAN PEMBAHASAN}

\subsection{Kondisi Sosial Budaya Pascakemer dekaan di Kalimantan Selatan}

\subsubsection{Kehidupan Sosial Masyarakat}

Menjelang tahun 1950, daerah Kalimantan Selatan baru saja mengalami pasca- revolusi fisik melawan penjajah Belanda. Tahun 1949, dilakukan proklamasi Devisi IV ALRI Pertahanan Kalimantan, menandai bahwa bergabungnya kembali rakyat Banjar dalam negara kesatuan Republik Indonesia. Masa ini bagi masyarakat Banjar mulai dengan gairah baru, yaitu menata kembali segala persoalan pemerintahan yang tadinya masih kacau oleh adanya agresi Belanda ke2. Dapat dikatakan, segala masyarakat etnik yang sudah terlanjur ada di wilayah ini seperti etnik Banjar, Bukit, Jawa, Sunda, Sumatera, Madura, China, Arab, Bugis, dan sebagainya yang notabene memiliki kebudayaan sendiri, mulai menjalin hidup berdampingan dengan saling memahami aspek-aspek budaya satu 
dengan budaya lainnya. Meski mereka juga hidup (sebagian kecil) berbeda keyakinan dan kepercayaan kepada Tuhan Yang Maha Esa, tetapi memberikan toleransi yang cukup tinggi kepada masing-masing pemeluk agama.

Masyarakat Banjar di Kalimantan Selatan dikenal sebagai pemeluk agama Islam dan pemilik budaya Melayu Banjar. Dengan dua pemahaman ini tidak menyulit-kan bagi masyarakat etnik lain untuk melakukan kegiatan bersama-sama, sebab agama Islam yang memperlihatkan toleransi tinggi dengan budaya lainnya serta pemahaman budaya Melayu bagi etnik lain memudahkan terjadinya proses akulturasi di kalangan masyarakat yang berbeda latar belakang ini. Kalau demikian mereka berbeda, mungkin hanya dilihat dari aspek identitas etnik yang masih dipertahankan sebagai kelompok-kelompok yang memiliki ciri sosial tersendiri. Ini bisa dilihat dari identitas kampung yang diberi nama-nama daerah maingmasing seperti kampung Jawa, kampung Bugis, kampung Arab, kampung Pacinaan, kampung Sumatera, dan lain-lain.

Pada umumnya kehidupan dilaksana-kan dengan pertanian pasang surut dan penduduk yang berada di dekat laut atau danau bekerja sebagai nelayan. Sebagian lagi ikut berdagang. Pertanian pasang surut dilaksanakan enam bulan sekali masa kerja. Ini berarti banyak waktu luang yang dimiliki oleh masyarakat. Waktu luang ini dimanfaatkan oleh sebagian besar penduduk untuk mengaji masalah-masalah agama Islam, berdagang, atau merantau. Bagi mereka yang berdagang, biasanya dilakukan dengan mengejar pasar ke kampung-kampung, bahkan ada yang sampai keliling kawasan Kalimantan Selatan dan Kaliman-tan Tengah. Mereka yang memanfaalkan waktu luang ini untuk merantau, bisa bepergian sampai ke pulau-pulau lain. Mereka terkadang lupa pulang dan menjalin keluarga dengan etnik lain yang bukan orang Banjar. Kebanyakan masyarakat Banjar yang melakukan pengembaraan ke negeri orang, mereka harus mampu bertahan. Untuk itu, apa pun pekerjaannya harus mereka geluti secara gigih untuk dapat bertahan hidup di negeri orang, termasuk menjadi pengawal orang lain atau pun pesuruh.

Masyarakat Banjar yang bertahan di Banua Banjar, pada umumnya mereka bersekolah di pendidikan agama untuk beroleh pengetahuan keagamaan. Di samping sekolah agama mereka melakukan pekerjaan bertani. Karena itu, sering mereka ini dipandang agamis, sebab memang tradisi mengkaji masalah-masalah kehidupan ber-gama ini cukup menonjol di kalangan masyarakat. Bagi mereka yang senang berdagang mengejar pasar, sering pula ikut menjalin keluarga dengan anak gadis dari kampung lain. Mereka hertahan hidup di kampnng asal istrinya, beranak pinak. Mereka ini pada umumnya, cepat menyebar ke berbagai kampung di sekitar Kalimantan Selatan, tetapi juga ke daerah-daerah lain seantero Kalimantan seperti Kalimantan Timur dan Kalimantan Tengah.

\subsubsection{Fenomena yang Menonjol Tahun 1950-1959}

Perkembangan 1950-1959 sering disebut era orde lama dengan bermacam isu politik yang menonjol seperti gaya peme-rintahan parlementer atau demokrasi liberal. 
Semula Kalimantan hanya memiliki satu kawasan provinsi dengan ibu kotanya Banjarmasin. Banjarmasin dikenal sebagai kota tertua di kawasan Kalimantan. Tahun 1950, tepatnya tanggal 14 Agustus 1959 Gubernur Kalimantan Selatan melakukan pemekaran daerah dengan membentuk Provinsi Kalimantan Selatan dengan ibu Kotanya Banjarmasin, Provinsi Kalimantan Tengah dengan ibu Kotanya Palangkaraya, Provinsi Kalimantan Barat dengan ibu Kotanya Pontianak, dan Provinsi Kaliman-tan Timur dengan ibu Kotanya Balikpapan.

Dalam kurun waktu 1950-959 Kalimantan Selatan diisi oleh tiga sosok pemimpin yang mengepalai daerah provinsi ini, yaitu dokter Murjani tahun 1949-1953. Temenggung Ario Milono 1953-1957 dan Syarkawi 1957-1960. Sebagai daerah yang sejak awal menjalin kerja sama yang harmonis antara suku-suku lain di nusantara seperti Jawa, Sunda, Bugis, Dayak, Minang, Banjar, Madura mereka sama-sama memiliki visi dan misi yang sama untuk meningkatkan pembangunan di kawasan Kalimantan Selatan. Kebanyakan dorongan kebersamaan ini dimulai dengan dilaku-kannya kawin campur (pembauran) antara etnik yang satu dengan etnik yang lain. Hidup rukun ialah bagian dari cita-cita hidup sejak nenek moyang mereka yang giat ikut melawan penjajah Belanda yang ingin menanamkan pengaruhnya di tanah Banjar ini.

Situasi sosial politik bagi Kalimantan Selatan yang baru mengalami gairah baru dalam kancah politik Indonesia, member-kan iklim yang segar bagi berdirinya berbagai aliran kepartaian. Sejak itu, bermunculan beragam ideologi dan afiliasi politik. Konsep politik yang cukup menonjol saat itu ialah Nasakom (Nasional, Agama. dan Komunis). Kondisi perbedaan paham ideologis yang teraplikasikan dalam aliran kepartaian ini menyebabkan sering muncul konflik dan pertikaian antar-masyarakat. Konflik yang muncul dan lahir secara beragam, mulai dari masalah-masalah harga barang sampai masalah-masalah ketidakadilan dan kekuasaan yang semena-mena dalam anggota parlemen tidak jarang didemo dan mosi tidak percaya oleh penganut aliran partai dan idologi tertentu, sehingga membuat mereka tidak dapat bekerja menata arus pemerintahan secara baik.

Situasi gaduh dan ekslusif seperti ini juga dirasakan oleh para seniman dan budayawan yang tergabung dalam macam-macam kekuatan sosial politik di masya-rakat. Sering pula muncul seniman-seniman partisan yang hanya berjuang untuk kepentingan kelompoknya sendiri. Ini terlihat dari perbedaan-perbedaan persepsi berkenaan dengan aliran politik yang dialaminya. Unjuk kekuatan ini dimulai sejak dilaksanakannya pemilu 1955 di mana empat partai terkuat saat itu mendapatkan suara terbanyak, yaitu Partai Nasional Indonesia (PNI), Masyumi, Nahdatul Ulama (NU), dan Partai Komunis Indonesia (PKI). Pascapemilu 1955 ini persaingan antar pemilik partai dan segala organisasi underbow yang dipayungi oleh aliran politiknya rnasing-masing semakin kuat. Tidak jarang pula dampak dari perbedaan ini menimbulkan perpecahan dan pertikaian di sana sini. Namun, bagi mereka yang sadar akan perbedaan konflik tersebut sering hanya mencermarinya sebagai sebuah gairah politik, lain mereka dapat bersatu kembali dalam persepsi 
membangun Kalimantan Selatan. Bagi mereka yang hanya menggantungkan cita-citanya hidup dalam kancah politik, mereka konsisten menggantungkan hidupnya pada jalur ini.

\subsubsection{Kehidupan Seni Budaya}

Kuatnya persengketaan politis yang muncul akibat gairah baru dalam kancah pemerintahan parlementer menyebabkan pertumbuhan seni budaya di daerah Kalimantan Selatan tidak berjalan mulus, seperti halnya daerah-daerah lain di Indonesia. Hanya sedikit seniman yang mampu ambil bagian dalam gairah menumbuhkan seni budaya di Kalimantan Selatan. Kegiatan seni budaya yang cukup menonjol di tahun-tahun pascapemilu 1955, hanyalah kegiatan pentas drama. Itu pun dilakukan oleh kelompok yang memang menjadikan kegiatan seni budaya sebagai salah satu pekerjaan mereka. Sandiwara rakyat yang cukup menonjol pada tahun-tahun itu ialah Sanggar Artis Drama Amatir (Sanggada), (kelompok Sandiwara Alwardah, dan kelompok Sandiwara Sinar Baru. Di samping kegiatan pentas-pentas sandiwara rakyat, aktif dalam kegiatan seni budaya ini ialah seni-seni tradisi seperti madihin, lamut, wayang gung wayang urang, (damarwulan, gandut, dan bakisah. Seniseni yang mengandung unsur narasi sering dipakai untuk kegiatan penerangan di masyarakat atau juga sekaligus sebagai bahan hiburan masyarakat setelah mela-kukan pekerjaan bertani sepeiti seusai menanam padi atau seusai memanen. Sandiwara rakyat yang tumbuh di Kalimantan Selatan pentas mengejar pasar. Setiap ada kampung yang memiliki pasar tradisional, rombongan drama ini pergi melakukan pentas. Kegiatan pentas dari kampung ke kampung ini diasumsikan, pada setiap ada pasar selalu banyak didatangi pedagang atau mereka yang akan menjual barang dagangannya. Tidak jarang, kelompok sandiwara ini juga sampai ke daerah-daerah lain di Kalimantan Tengah, seperti; Sampit, Palangkaraya, Pangkalan-bun, Kapuas, Mandumai, Palingkau, Basa-rang, dan lain-lain.

Seni tradisi yang juga banyak memenuhi keinginan masyarakat ialah madihin, lamut, dan wayang kulit. Seniseni ini juga sering mengejar permintaan ke kampung-kampung sesuai keinginan panitia penyelenggara kegiatan yang biasanya juga memanfaatkan untuk mencari dana men-dirikan sekolah, surau, atau membangun sarana-sarana umum lainnya. Meski kehi-dupan seni budaya ini tidak semapan seperti masa kini, tetapi cukup memberi arti bagi perkembangan seni budaya di daerah. Untuk seni madihin yang diketahui banyak melakukan pergelaran di kampung-kam-pung ialah pasangan almarhum Yunan dan Saniah. Kesenian lamut yang juga mengikuti peermintaan masyarakat yang bernazar atau yang menghibur malam perkawinan ialah almarhum Ganggas dan almarhum Marzuki, sedangkan kesenian wayang kulit yang sangat populer pada saat itu ialah almarhum dadalang Tulur dari Barikin, Barabai Kabupaten Hulu Sungai Tengah. Kehidupan seni tradisi pada kurun waktu ini cukup memberi arti bagi kehidupan seniman untuk mencari nafkah. Hal ini karena misi hiburan pada saat itu hanya yang populer ialah seni tradisi.

Ada dua kondisi sosial budaya yang dapat dicatat pada kurun waktu ini, 
pertama ialah tradisi lisan masih sangat kuat berakar di masyarakat. Oleh karena itu. seni yang berkembang populer pada saat itu ialah seni tradisi yang memang berkembang dari mulut ke mulut. Kedua, kehiduapn sosial masyarakat pada saat itu, khsususnya yang berada di kampung-kampung tidak banyak dipengaruhi oleh pikiran-pikiran kehidupan modern. Meski-pun suasana pada saat itu, sudah mulai digelar layar-layar tancap, tetapi tempat penyelenggaraan film-film layar tancap tersebut hanya di sekitar ibu kota pro-vinsi. Alat komunikasi yang masih dipandang modern pada saat itu yaitu radio. Itu pun hanya orang-orang tertentu yang memilikinya. Boleh jadi, seni rakyat merupakan pilihan satu-satunya untuk menghibur masyarakat.

Di samping itu, bentuk-bentuk perge-laran kesenian yang tumbuh di masya-rakat banyak dimanfaatkan untuk kepen-tingan mencari dana. Waktu penyeleng-garaan acara pertunjukan pun yang ramai dikunjungi masyarakat hanyalah situasi pada saat setelah panen padi. Pada saat itu, sekaligus dijadikan momen untuk memu-lerkan tokohtokoh seniman. Namun, seperti terungkap dalam bagian latar sosiopolitik masa lain, seniman-seniman ini juga sebetulnya berada dalam kekuatan sosial politik tertentu. Sehingga, apa yang diperge-larkannya juga lebih banyak menyuarakan kepentingan politiknya. Lemahnya kondisi tulis menulis masyarakat pada saat itu, membuat perkembangan seni budaya atau sastra tradisi di Kalimantan Selatan tidak dapat dicatat secara akurat. Hal-hal yang dapat diketahui dari perkembangan itu, hanyalah informasi-informasi yang diper-oleh dari narasumber yang pada saat itu sebagai pelaku seni.

\subsection{Sastra Indonesia di Kalimantan Sela- tan Tahun 1950-1959}

\subsubsection{Kedudukan dan Fungsi Sastra di Tengah Perkembangan Seni Lain}

Pertumbuhan sastra Indonesia di Kalimantan Selatan pada periode 1950-1959 masih berada dalam kondisi awal. Dorongan yang pertama diperoleh dari orang-orang terpelajar, seperti para guru dan anggota-anggota organisasi masyarakat pada saat itu. Bagi masyarakat Banjar, sastra tulis memang belum berkembang subur, hal ini karena kegiatan tulis-menulis belum merupakan bagian dari trend berkegiatan pada saat itu. Dapat dikatakan kedudukan dunia sastra di masyarakat saat itu, hanyalah upaya mengikuti perkem-bangan media massa yang banyak menulis karyakarya sastra di surat-surat kabar yang masih dapat dibaca. Salah satu fungsi yang diikuti oleh para penulis Kalimantan Selatan ialah, menulis sastra sama dengan menyu-arakan misi-misi politik, kehidupan dan romantisme. Karena itu, karya-karya prosa yang banyak beredar pada saat itu juga karya-karya romantis yang memaparkan kehidupan percintaan dua anak manusia.

Kehidupan media penerbitan sangat menetukan bagi muncul dan lahirnya kegialan tulis menulis pada saat itu. Beberapa media massa yang saat itu sudah banyak menulis karya sastra ialah; surat kabar Mingguan Kalimantan, yang terbit di Banjarmasin, majalah Kenangan, majalah Pahatan juga terbit di Banjarmasin antara tahun 1950-1953. Ada pula surat kabar Harian Indonesia Berjuang (1952), surat kabar Harian Indonesia Merdeka 
(1953), majalah Pengha-rapan (1951), majalah Perjuangan (1953), majalah Terompet Islam (1955), dan surat kabar Utusan Kalimantan (1957). Dengan media masa ini para penulis Kalimantan Selatan lebih leluasa menyuarakan misi-misi idealiasme mereka.

Mulainya sastrawan yang berkiprah dalam sastra tulis ini, kehidupan seni budaya yang cenderung diisi oleh sastra tradisi (sastra lisan) seperti lamut, bakisah, madihin, pantun, bapandung, dan lain-lain. Seni-seni sastra yang dilulis oleh sastrawan Kalimantan Selatan banyak menghiasi surat kabar, bahkan ada roman-roman yang diterbitkan di luar daerah ini membuat gairah penulisan prosa semakin tinggi. Walaupun kegiatan ini juga berimbang dengan kegiatan seni tradisi, tetapi rupanya keadaan ini tidak menyurutkan mereka yang melakukan seni rakyat yang memang berkembang secara otodidak. Para pembaca sastra modern di Kalimantan Selatan rupanya masih belum terbentuk. Saat itu, masih banyak terdapat masyarakat yang buta huruf, sehingga bentuk-bentuk karangan yang ditulis oleh para pengarang Kalimantan Selatan tidak banyak diketahui oleh masyarakat banyak. Hanya beberapa rekan mereka yang mengetahui, sedangkan masyarakat awam kebanyakan tidak mengetahuinya.

Masyarakat umum, di luar mereka yang terpelajar kebanyakan hanya mema-hami konteks bahasa tulis Arab Melayu yang dimangfaatkan untuk baca tulis kitab-kitab kuning dan kitab-kitab pelajaran agama. Oleh karena itu, sastra tradisi yang populer pada kurun waktu itu masih didominasi oleh kegiatan baca syair dan hikayat. Syair ialah bentuk sastra lama yang cukup populer di kalangan masyarakat Banjar. Kegiatan baca syair ini dilakukan hampir setiap ada pertemuan. Syair-syair yang sering dibacakan pada saat itu ialah syair yang berisi nasihat, syair keagamaan, dan syair riwayat para nabi. Fungsi baca syair ini lebih banyak untuk menyampaikan pepatah dan ajaranajaran moral tentang agama Islam atau untuk memperbaiki ahlak bagi manusia. Berbeda dengan itu, sastra Indonesia hanya bisa dikenal oleh kalangan terpelajar yang banyak memaparkan persoalan-persoalan kehidupan masyarakat modern. Kehidupan masyatakat modern bagi masyarakat Banjar di tahun-tahun itu tidak dikenal populer. Hal ini karena kuatnya pengaruh ajaran agama yang senantiasa menjaga aspek kehidupan yang dapat merusak kedudukan mereka.

\subsubsection{Sastra Indonesia di Kalimantan Se- latan Bagian dari Sastra Nasional}

Meskipun sastra Indonesia pada tahun 1950-1959 tidak begitu populer di kalangan masyarakat, tetapi apa yang mereka suarakan dalam laras bahasa Indo-nesia dapatlah dimaklumi sebagai bagian dari sastra nasional. Mereka menyuarakan hal-hal yang berkaitan dengan fungsi bahasa nasional dan kebanyakan misi-misinya juga tidak membawa warna kedaerahan. Ini terbukti dari tuilisantulisan yang mereka kirimkan berkenaan dengan sastra, lebih banyak dikirimkan ke media massa yang terbit di luar daerah seperti majalah Dupa dan majalah Rindu (1953-1957) yang terbit di Medan. Kemudian majalah Gajah Mada yang terbit di Yogyakarta. Ada lagi sejumlah majalah yang terbit di Jakarta seperti majalah Budaya, majalah Cermin, majalah Garuda, 
majalah Indonesia, majalah Kisah, majalah Siasat, majalah Media, majalah Merdeka, majalah Mimbar Indonesia, majalah Pemuda, majalah Panca, majalah Teruna, dan majalah Zenith. Kehadiran tulisan-tulisan sastrawan Kali-mantan Selatan melalui majalahmajalah dan surat kabar yang terbit di luar daerah mem-buat mereka justru populer di luar daerah.

Apa yang disuarakan oleh sastrawan nasional pada saat itu masih berkaitan erat dengan persoalan politik dan kemerdekaan. Hal-hal politik, secara nasional pada periode ini memang cukup memberi warna, seperti ramainya polemik kebudayaan antara Timur dan Barat oleh Sutan Takdir Ali Syahbana dan Armin Pane. Di samping itu, banyak pula senimanseniman yang berada di bawah kekuatan sosial politik tertentu dengan underbow Lekra. Hal demikian membuat seniman-seniman, khususnya komunitas sastrawan pada saat itu cenderung terpecah. Namun demikian, mereka masih fokus berbicara masalah-masalah nasional seperti masalah moral, keadilan, identitas nasional romantisme bergaya Timur, dan lain-lain. Oleh karena itu, sangat diyakini pula bahwa apa yang ditulis oleh sastrawan Kalimantan Selatan, meskipun dalam jumlah yang amat terbatas juga menjadi bagian dari akumulasi pertumbuhan sastra nasional.

Seiring dengan berlakunya penggunaan bahasa Indonesia untuk seluruh masyarakat Indonesia, hal ini lebih memungkinkan mereka dapat membaktiknn karya-karya mereka sejajar dengan apa yang ditulis oleh sastrawan-sastrawan daerah lain yang juga menggunakan bahasa Indonesia sebagai alat penghubungnya. Memang pada saat itu, bahasa Melayu masih kuat sebagai bahasa pergaulan antarmasyarakat, tetapi lambat laun pemakaian bahasa Melayu ini sudah banyak bertukar dengan bahasa Indonesia. Secara psikologis, seluruh masyarakat Indonesia telah sepakat menerima bahasa Indonesia sebagai bahasa nasional, meskipun ejaan yang berlaku pada saat itu ialah Ejaan Republik (Ejaan Soewandi). Bagi masyarakat Banjar di Kalimantan Selatan, memang pemakaian bahasa Indonesia dengan Ejaan Republik ini tidak terlalu populer. Sebagian besar mereka masih mengenal bahasa Melayu dengan beragam dialek daerah, seperiti dialek Banjar Hulu dan Banjar Kuala.

Meski perkembangan di Pulan Jawa, Sumatera, dan Bali kondisi kepengarangan sudah demikian maju seperti terbitnya berbagai roman, novel, dan puisi-puisi di bawah naungan Balai Pustaka dan angkatanangkatan setelah periode itu, tetapi karya-karya itu tidak begitu menyebar di kalangan masyarakat. Justru banyak mengenal karya-karya tersebut ialah kalangan dunia pendidikan (sekolah), bukan kalangan masyarakat awam. Hal demikian banyak memengaruhi masyarakat Banjar di Kalimantan Selatan pada kurun waktu itu, sastra tulis dalam bentuk penulisan syair berbahasa Banjar dalam bentuk huruf Arab Melayu. Kebanyakan ini berkembang di pesantren-pesantren. Syair itu direproduksi dalam tulisan Arab Melayu berbahasa Banjar. Isinya pun dianggap sakral, sebab semua syair yang ditulis ini bertutur tentang masalah ajaran moral, keagamaan, dan silsilah para nabi. Lebih dari itu, bentuk karya sastra asing yang sudah memenuhi pikiran masyarakat, yakni kisah seribu satu malam. Kisah-kisah itu dibawakan oleh para penutur cerita 
dari kampung ke kampung. Tokoh pencerita yang juga menggunakan bahasa Melayu Banjar ini ialah seorang guru yang bernama Arpan (19551964), Artum Ali (1957-1969). Kedua penutur kisah seribu satu malam yang berisi nasihat dan pepatah dalam ajaran Islam ini sudah mulai menggabungkan antara bahasa Banjar dengan bahasa Indonesia. Sehingga, penikmat masyarakat Banjar pada saat itu, sudah mulai mengenal bentuk-bentuk pemakaian bahasa Indonesia. Tampaknya, belum populernya bahasa Indonesia pada periode itu menyebabkan gerakan penulisan dan minat baca terhadap sastra Indonesia masih berada di bawah popularitas sastra lisan berbahasa Banjar.

\subsection{Sistem Kepengarangan}

\subsubsection{Sistem dan Gaya Pengungkapan}

Pada umumnya gaya pengungkapan para sastrawan Kalimantan Selatan pada periode 1950-1959 bersifat umum, maksudnya tema-tema yang dipilih ialah yang bersifat umum tergantung pada inspirasi yang dimiliki oleh para sastrawannya sendiri. Meskipun latar belakang sosial politik cukup menonjol dan tidaklah terlalu mempengaruhi ikhwal penulisan. Namun, gaya yang mereka ikuti pada umumnya juga seperti bahasa peliputan wartawan. Sehingga tampak amat gamblang jika menyuarakan sesuatu dalam karangan mereka. Cerpen misalnya, lebih memilih pengungkapanpengungkapan sebagai mana prinsip 5 $\mathrm{W}+1 \mathrm{H}$ hal ini karena prinsip-prinsip dalam penulisan berita amat memengaruhi karya-karya mereka. Meski demikian masih terdapat karangan-karangan prosa yang diakui bahwa setiap nama-nama pelaku atau tokoh dalam karangan tersebut bersifat fiktif.

Rata-rata pengarang masa ini tidak menggunakan nama-nama samarannya. Hal ini karena upayaupaya memperkenalkan diri di kalangan pengarang Kalimantan Selatan sudah mulai bermunculun. Dengan nama-nama pengarang langsung yang dicantumkan dalam karangannya dimak-sudkan penulisnya dapat semakin dikenal. Hal ini berbeda dengan pengarangpengarang generasi sebelumnya yang lebih banyak menggunakan nama samaran. Mereka lebih senang bersembunyi di balik nama samaran tersebut. Di sisi lain, nama samaran menunjukkan bahwa masih kuatnya tradisi lisan sebagai panutan dalam bersikap di kalangan masyarakat.

Menurut seorang narasumber Haji Artum Artha yang dianggap banyak mengetahui ikhwal kepengarangan pada periode 1950-1959 tersebut, gaya yang mereka anut ialah gaya langsung. Dialog-dialog yang diungkapkan dalam karangan adalah langsung dicantumkan seperti dalam kutipan langsung. Ada kemungkinan agar karangan tersebut seakan-akan benar terjadi atau seditidak-tidaknya pengarang berlaku sebagai orang yang paling tahu.

Dalam hal penulisan puisi, apa yang ditulis oleh sastrawan Kalimantan selatan lebih banyak menyuarakan tema-tema yang bersifat nasional. Warna lokal mereka tinggalkan berganti dengan bentuk-bentuk yang menyuarakan sesuatu yang bersifat universal. Ini bisa dicermati bahwa munculnya sikap nasionalisme yang tinggi di kalangan sastrawan Kalimantan Selatan. Boleh jadi, sikap ini merupakan realisasi sikap politik pengarang yang seirama dengan sikap 
politik pejuang masa lalu yang menyatakan diri ingin bergabung dengan republik pasca proklamasi Devisi IV ALRI Pertahanan Kalimantan.

\subsubsection{Sistem Publikasi}

Sebenarnya untuk kegiatan publikasi para sastrawan Kalimantan Selatan pada periode ini tidak terlalu sulit. Ini disebabkan, mereka sendiri bekerja sebagai wartawan atau penulis-penulis lepas di berbagai media massa, baik yang terbit di Kalimantan Selatan maupun yang berada di luar Kalimantan Selatan. Mereka pada umumnya sudah dikenal oleh tim redaksi surat kabar tersebut. Lebih dari itu, sastrawan Kalimantan Selatan sendiri sudah saling mengenal, sehingga upaya-upaya saling membantu untuk melakukan publikasi pada saat itu lebih mudah. Hanya yang menjadi kesulitan ialah publikasi-publikasi berupa buku atau naskah-naskah kumpulan puisi, kumpulan cerpen, roman agak sulit diterbitkan, sebab ini menyangkut kesiapan dan kesediaan perusahaan menerbitkan karya tersebut. Akibatnya ada karya sastra yang sudah lama sekali ditulis, tetapi tidak atau belum diterbit-kan oleh penerbit.

Kebanyakan karya-karya ini diketik sendiri dengan rangkap karbon sampai tiga lapis. Lapisan pertama dikirimkan ke penerbitan, lapisan kedua menjadi arsip, sedangkan lapisan ketiga dipersiapkan untuk kembali dikirim jika kiriman pertama hilang. Mereka yang masih mampu mencetak secara stensilan karya-karya ini mnsih dapat menyebarkan ke rekan-rekannya sejawat atau ke perpustakaanperpustakaan, tetapi keadaan seperti ini jarang terjadi sebab usaha menerbitkan dengan stensilan juga memerlukan biaya.

Kalau dicermati dari kegiatan penye-baran informasi dari media massa yang terbit dan memuat karyakarya sastrawan ini tampaknya tidak terlalu diragukan. Sebab media-media massa pada saat itu sudah mulai mudah menyebar ke daerah-daerah di Indonesia. Di samping media massa luar yang memuat karya sastra sastrawan Kalimantan Selatan juga masih terdapat beberapa penerbitan yang mau memuat karya-karya sastra mereka.

\subsubsection{Sistem Pembaca}

Kalimantan Selatan pada periode 1950-1959 tergolong masih baru dalam penataan pembangunan daerah ini. Kegiatan sosial politik di daerah ini baru memperoleh titik awal setelah tahun 1949, setelah proklamasi Devisi IV ALRI pertahanan Kalimantan. Keadaan ini pun masih terganggu lagi oleh peristiwa-peristiwa internal pemerintah pusat dan para pejuang Kalimantan Selatan yang pada saat itu dianggap sebagai pemberontak oleh peme-rintah pusat. Keadaan itu tidak mengun-tungkan bagi masyarakat, karena hidup tidak tenang dan kegiatan-kegiatan pen-didikan untuk lepas dari ketidakmampuan membaca tidak berjalan secara merata. Pada saat itu hampir $70 \%$ masya-rakat Kalimantan Selatan tidak mampu membaca huruf-huruf latin, kecuali generasi muda yang pada saat itu masih sempat bersekolah. Selebihnya ialah para pejuang dan orang-orang dewasa yang tidak sempat lagi mengikuti sekolah secara terencana.

Kondisi ini mengakibatkan, apa yang ditulis oleh para sastrawan, baik berupa puisi, prosa, maupun tulisantulisan lainnya hanya beredar di 
kalangan sastrawan sendiri, sedikit sekali beredar di kalangan masyarakat. Kecuali itu, para guru yang mengajar di sekolah-sekolah dasar yang terkadang hanya memanfatkan karyakarya tersebut untuk dibaca sebagai bahan penga-jaran siswa-siswa mereka. Keadaan itu menyebabkan tidak terbentuk sistem pembaca yang baik untuk karya-karya sastrawan Kalimantan Selatan sendiri. Pada periode 1950-1959 yang banyak beredar di sekolah-sekolah melaluli buku-buku gemar membaca cetakan dari pusat. Buku inilah yang banyak dibaca anak-anak sebab bukunya juga cukup menarik karena penyajiannya dilengkapi dengan gambar-gambar visual berwarna warni, sedangkan buku-buku sastra hampir tidak ada yang beredar di kalangan para guru.

Sebagai daerah yang baru membangun, kondisi sosial budaya Kalimantan Selatan pada saat itu masih belum memiliki perpustakaan yang reptesentatif yang juga memuat karya-karya penyair daerah sendiri. Kebanyakan buku-buku yang tersedia di perpustakaan juga hasil terbitan pemerintah Belanda. Karya-karya sastra yang ditulis oleh sastrawan Kalimantan Selatan keba-nyakan dikirimkan ke media massa luar. Arsip-arsip yang diperlukan untuk krea-tivitas kepengarangan masingmasing tidak sempat terbukukan secara memadai. Ini berakibat, ratarata sastrawan Kaliman-tan Selatan tidak memiliki arsip atas karyanya sendiri, meskipun karya itu sudah diterbitkan oleh media massa luar.

\subsubsection{Sistem Kritik}

Lemahnya sistem pembaca di kalangan masyarakat menyebabkan lemahnya pula kegiatan apresiasi sekaligus kegiatan kritik sastra.
Kegiatan-kegiatan kritik sastra hanya dilakukan secara sederhana, seperti kegiatan kumpul-kumpul membicarakan karya-karya sastra secara sederhana. Itu pun hanya dilakukan lebih banyak untuk kepentingan silaturrahim. Konon menurut seorang narasumber (Haji Artum Artha) yang banyak membicarakan dalam kumpul-kumpul pembicaraan sastra ialah persoalan misi-misi cerita. Tema-tema yang berkaitan dengan keunikan cerita. Gambaran cerita yang dapat mengisahkan peristiwa tertentu oleh tokoh tertentu di tempat tertentu merupakan cerita-cerita yang unik. Kemam-puan mengggambarkan sindiran-sindiran dengan cerita tersebut, ialah keunikan tersendiri di kalangan sastrawan. Namun, pembicaraan tersebut jarang sekali dilulis melalui media massa, sehingga satu pun tidak ada arsip yang ditemukan tulisan-tulisan yang berkaitan dengan kritik sastra.

Kalangan sastrawan sendiri yang sering menanggapi dan menuliskan analisis sastra melalui esai-esai sastra hanya bersifat apresiatif. Kritik sastra pada masa itu belumlah populer seperti sekarang ini. Tulisan-tulisan yang bermunculan pada saat itu menurut Hijaz Yamani juga bersifat tulisan lepas, maksudnya tidak rutin di tulis di media massa. Yang paling banyak memang ditulis oleh penulispenulis luar. Ada beberapa tulisan yang ditulis oleh pengamat daerah lain untuk menanggapi karya-karya sastra sastrawan Kalimantan Selatan, tetapi keadaan seperti ini lidak berlaku rutin. Jika mereka tertarik dengan salah satu karya yang sampai kepadanya, barulah dia menulis, kalau tidak mereka akan biarkan. Meski demikian, sistem kritik pada periode 
itu masih ada tetapi dilakukan oleh pengamat-pengamat sastra dari luar, yang secara kebetulan juga menerima majalah atau surat kabar yang memuat karya-karya sastrawan Kalimantan Selatan.

\subsubsection{Sistem Produksi}

Kegiatan produksi sastra untuk sastrawan Kalimantan Selatan tampak-nya amal tergantung pada media pener-bitan. Implikasi dari kegiatan itu bisa dilihat dari sifat kegiatan yang bersifat insidentil untuk mengirimkan karya-karya ke media massa. Meski demikian, masih terdapat banyak sastrawan yang secara rutin mengirimkan karya-karya mereka ke berbagai media massa baik yang diterbitkan di daerah atau di luar Kalimantan Selatan. Jika media yang dituju mau memuat karya-karya yang diproduksi, maka sastrawan pun menulis lebih produktif, sedangkan jika media jarang memuat karya-karya yang dikirimkan oleh penu-lis, maka ia mulai malas. Namun, para pengarang masih mau mengirimkan ke media lainnya. Karena itu, terkadang di media yang satu tidak diterima, tetapi di media lain dapat dimuat. Menurut Yustan Aziddin (dari ceramah tahun 1994), karya sastra yang dikirmkan ke media tertentu, tetapi tidak dimuat atau di kem-balikan, lalu dikirmkan lagi dengan pergantlian judul atau dengan nama samaran akhirnya dapat dimuat. Jadi, menurut kesimpulan beliau, ukuran dapat dimuat atau tidaknya sebuah karya sastra terkadang tidak bisa diukur dengan pikiran-pikiran literer.

Kenyataannya karya yang sama tetapi dengan perubahan judul dan per-gantian nama pengarang akhirnya karya tersebut dapat dimuat. Atau dapat juga terjadi, karyn tertentun tidak bisa dimuat pada media tertentu, tetapi masih bisa dimuat selelah dikirimkan ke media lain.

Pada periode 1950-1959 sistem produksi karya sastra hanya dilakukan oleh sastrawan sendiri. Upaya-upaya penulisan dilakukan secara sederhana terkadang hanya bertulis tangan dan bagi yang sudah memiliki mesin ketik dapat menuliskannya secara rapi. Kebanyakan yang dilakukan oleh sastrawan ialah ikut mengetik di instansi atau jawatan tertentu seperti penerangan atau kantor-kantor yang memiliki mesin ketik. Jika sastrawan ingin menggandakan karya tersebut, mereka melakukan pengetikan dengan beberapa kali ulang. Jika ingin menggandakan secara lebih banyak lagi mereka mengetiknya di atas kertas buram yang kemudian distensil. Biaya yang dikeluarkan untuk keperluan itu juga ditanggung oleh sastrawan sendiri. Karya sastra yang digandakan dengan stensilan itu juga tidak dijual. Sastrawannya hanya membagikan kepada kalangan sastrawan sendiri atau mengirimkan ke sekolah-sekolah yang sudah dikenal oleh sastrawanya sendiri.

Produksi karya sastra biasanya hanya dilakukan ketika sastrawan mengirimkannya ke media massa di luar Kalimantan Selatan, apakah lembaga penerbitan buku atau sekadar untuk dimuat di majalah atau surat kabar. Kebanyakan sistem produksi ini hanya dilakukan secara insidentil dan tidak terprogram secara khusus, misalnya untuk keperluan bacaan di sekolah. Haji Artum Artha mengaku buku-buku beliau banyak diterbitkan di luar Kalimantan Selatan oleh penerbit luar, sebab ia ialah seorang wartawan. Faktor dikenalnya seorang sastrawan oleh media tertentu 
sangat menentukan sebuah karya sastra dapat diterbitkan atau dimuat di media massa cukup menentukan.

\section{PENUTUP}

Perkembangan sastra di Kalimantan Selatan tahun 1950-1959 merupakan kelanjutan dari periode sebelumnya, yakni masa penerus. Masa ini ditandai dengan berbagai macam isu politik seperti gaya pemerintahan parlemenler dan demokrasi liberal. Di samping itu, pasca proklamasi Devisi IV ALRI Pertahanan Kalimantan menyadarkan para sastrawan untuk menyuarakan tema-tema penulisan sastra yang bersifat universal. Selain itu, kesadaran kepengarangan bagi sastrawan Kalimantan Selatan pada pascakemerdekaan I950-1959 sudah menjadikan bahasa Indonesia sebagai sarana pemersatu, sehingga terjadi toleransi yang tinggi dengan budaya lain, sehingga memudahkan terjadinya proses akulturasi di kalangan masyarakat yang berbeda latar belakang budaya.

Sastrawan Kalimantan Selatan yang mendalami dunia sastra pada masa itu, pada umumnya mereka yang berprofesi sebagai wartawan, guru, dan pengurus organisasi masa. Kehidupan dunia sastra pada saat itu juga sangat ditentukan oleh munculnya berbagai penerbitan, seperti surat kabar dan majalah. Kebanyakan karya-karya sastra modern yang menandai periodisasi itu dimuat juga di berbagai media luar Kali-mantan Selatan. Meskipun tradisi lisan masih merupakan budaya yang berakar kuat di kalangan masyarakat Banjar, tetap masih terdapat banyak pengarang yang mencu-rahkan tulisannya melalui bentuk-bentuk sastra Indonesia modern. Budaya lisan masih kuat berakar bahwa menjadi pola pikir yang cukup memengaruhi para sastrawan Kalimantan Selatan. Ini dapat dilihat dari karya sastra yang telah dimuat di media massa, tidak semuanya menjadi milik pribadi sastrawan.
Ini berakibat gerakan pengarsipan pada masyarakat Banjar men-jadi lemah.

Selain itu, Sistem kepengarangan sastrawan Kalimantan Selatan kebanyakan juga masih dipengaruhi oleh gaya profesi wartawan, yakni lahirnya karya sastra prosa bercorak reportase. Kesan ini muncul dari bentuk penyajian unsur-unsur dramatik yang menonjol dialog-dialog langsung dan sedikit bergaya naratif. Sistem publikasi yang terjadi pada masa ini juga lebih ditunjang oleh penerbitan yang ada di luar daerah. Meskipun di Kalimantan Selatan pada masa ini sudah mulai terdapat banyak penerbitan, tetapi belum banyak yang bersedia menerbitkan karya-karya sastra hasil pengarang Kalimantan Selatan, kecuali dalam bentuk muatan surat kabar dan majalah. Publikasi yang juga dilakukan oleh para sastrawan ialah menggandakan karya sastra dalam bentuk stensilan yang dibagikan kepada kalangan sastrawan sendiri. Sistem pembaca tidak bisa berjalan baik karena hasil-hasil tulisan sastra belum tersedia di perpustakaan. Hampir 50 persen masyarakat Banjar usia sekolah tidak mampu membaca huruf-huruf latin. Hal itu menyebabkan karya sastra pengarang Kalimantan Selatan tidak dibaca dan tidak banyak dikenal oleh masyarakat. Sistem kritik sastra pada masa ini juga belum muncul seperti sekarang, Kebanyakan pembicaraan yang dilakukan masih bersifat apresiatif dari pertemuan ke pertemuan. Yang banyak melakukan tulisan-tulisan yang bernada kritik sastra hanyalah redaksiredaksi media massa yang ada di luar Kalimantan Selatan. Sistem produksi sastra yang dilakukan oleh sastrawan Kalimantan Selatan bersifat insidentil, yakni saat munculnya inspirasi untuk menuliskan karya sastra barulah mereka tulis. Meski demikian masih terdapat banyak sastrawan yang menciptakan karya sastra secara rutin untuk dikirimkan ke berbagai media massa di luar Kalimantan Selatan. 


\section{DAFTAR PUSTAKA}

AG, Linus Suryadi. 1987. Tonggak 2: Antologi Puisi Modern. Jakarta: PT Gramedia.

Aziddin, Yustan. 1975. Pengajaran Sastra. Skripsi Sarjana. Banjarmasin: Jurusan Pendidikan Bahasa dan Seni Program Studi Bahasa dan Sastra Indonesia FKIP Unlam.

Damono, Joko Sapardi. 1983. Beberapa Catatan Tentang Penulisan Sejarah Sastra Pengantar. Jakarta: Pusat Pembinaan dan Pengembangan Bahasa.

. 1984. Sosiologi Sastra, Sebuah Pengantar Ringkas. Jakarta: Pusat Pembinaan dan Pengembangan Bahasa.

Effendi, Rustam dkk. 1993. Kesusastraan Indonesia di Kalimantan Selatan. Laporan Penelitian. Banjarmasin: Proyek Pembinaan Bahasa dan Sastra Indonesia dan Daerah Kalimantan Selatan.

Jarkasi dkk. 1996. Sejarah Pertumbuhan Sastra Indonesia di Kalimantan Selatan 1930 - 1949. Laporan Penelitian. Banjarmasin: Proyek Pembinaan Bahasa dan Sastra Indonesia dan Daerah Kalimantan Selatan. . 2002. Sastra Indonesia di Kalimantan Selatan Priode Tahun 1950-1959. Laporan Penelitian. Banjarmasin: Bagian Proyek Pembinaan Bahasa dan Sastra Indonesia dan Daerah Kalimantan Selatan.

Jarkasi dan Tajuddin Noor Ganie. 2001. Sketsa Sastrawan Kalimantan Selatan. Banjarmasin: Balai Bahasa Banjarmasin.

Mujiningsih, Erlis Nur 1995. Biografi Selasih dan Karyanya. Jakarta: Pusat Pembinaan dan Pengembangan Bahasa, Departemen Pendidikan dan Kebudyaan.

Selden, Rama. 1996. Panduan Pembaca Teori Sastra Masa Kini. Jogjakarta. Gajah Mada University Press.

Sukma, Merayu. 1950. Poetra Mahkoeta yang Terboeang. Medan: Penerbit Antara.

Wellek Rene dan Austin Warren. 1989. Teori Kesusastraan. Penerjemah Melani Budianta dari buku Theory Of Literature. Jakarta: PT Gramedia.

Teeuw, A. 2013. Sastra dan Ilmu Sastra. (Pengantar Teori Sastra). Jakarta: Pustaka Jaya. 